\title{
Perencanaan Strategi Sistem Informasi untuk Mendukung Proses Bisnis Hotel XYZ
}

\author{
Putri Nastiti $^{1 *}$, Alwi Kesuma ${ }^{2}$, Marvin Ariel Johannes ${ }^{3}$, Christian Immanuel ${ }^{4}$ \\ ${ }^{1234}$ Program Studi Sistem Informasi, Universitas Atma Jaya Yogyakarta, Indonesia \\ Email: ${ }^{1 *}$ putri.nastiti@uajy.ac.id
}

(Naskah masuk: 14 Apr 2021, direvisi: 19 Jun 2021, diterima: 21 Jun 2021)

\begin{abstract}
Abstrak
Hotel merupakan salah satu contoh infrastruktur yang dapat mendukung pariwisata di suatu daerah. Di era digital seperti saat ini, banyak hotel yang melakukan pemasaran digital supaya dapat menjangkau lebih banyak wisatawan. Hal ini menjadi bentuk nyata bahwa sistem informasi menjadi landasan bagi pengembangan sebuah organisasi modern, salah satunya adalah industri perhotelan. Oleh karenanya setiap organisasi perlu didukung oleh rancangan arsitektur sistem informasi untuk pengembangan bisnis organisasinya. Arsitektur perusahaan akan mendukung model bisnis fungsional yang dapat disesuaikan dengan berbagai macam kegiatan pelayanan publik. Penelitian ini mengambil objek Hotel XYZ yang terletak di kota Yogyakarta. Arsitektur perusahaan pada penelitian ini akan dilakukan berdasarkan langkah-langkah dalam kerangka kerja The Open Group Architecture Framework (TOGAF). Tahapan yang dilakukan meliputi arsitektur visi, arsitektur bisnis, arsitektur data, arsitektur aplikasi, dan arsitektur teknologi. Alat analisis yang digunakan dalam penelitian ini diantaranya adalah analisis rantai nilai, analisis SWOT, dan business model canvas. Selain itu penelitian ini juga menghasilkan usulan aplikasi sistem informasi dan rencana arsitektur teknologi, yaitu sebuah sistem perbaikan untuk unit front office, dimana sistem all in one control yang saat ini dimiliki oleh Hotel XYZ dengan basis data terpusat dapat terintegrasi dengan platform afiliasi sistem tiket lainnya menggunakan API. Usulan strategi SI untuk unit front office ini juga didukung dengan usulan arsitektur teknologinya. Implementasi perencanaan SI/TI ini akan mendukung proses bisnis Hotel XYZ menjadi lebih efektif dan efisien.
\end{abstract}

Kata Kunci: arsitektur perusahaan, TOGAF, perhotelan

\section{Information System Strategic Planning to Support Hotel XYZ Business Process}

\begin{abstract}
Hotel is one of the infrastructure that can support tourism industry. In the digital era, many hotels are implementing digital marketing so they can reach more tourists. This is a tangible form that information systems become the basis for the development of a modern organization, one of which is the hotel industry. Therefore, every organization needs to be supported by an information system architecture design for the development of its organization's business. The company architecture will support a functional business model that can be adapted to various public service activities. This study takes Hotel XYZ as the research object. Hotel XYZ is located in the Yogyakarta. The architecture eterprise will be carried out based on the steps of The Open Group Architecture Framework (TOGAF). The phases include vision architecture, business architecture, data architecture, application architecture, and technology architecture. This research used analytical tools include value chain analysis, SWOT analysis, and the business model canvas. In addition, this research also propose information systems strategy and technology architecture plans. The implementation of information technology in supporting the Hotel XYZ business process will be more effective and efficient if it is supported by an enterprise architecture planning.
\end{abstract}

Keywords: enterprise architecture, TOGAF, hospitality 


\section{PENDAHULUAN}

Pariwisata merupakan salah satu sektor yang menjadi perhatian pemerintah, baik pemerintah pusat maupun pemerintah daerah. Seperti yang terjadi di Provinsi Daerah Istimewa Yogyakarta, pada tahun 2019 peringkat sektor pariwisata dalam sumbangsihnya terhadap Product Domestic Regional Bruto (PDRB) mengalami kenaikan. Dari total 17 sektor lapangan usaha, sektor pariwisata berada di tingkat kedua [1]. Berbagai industri yang ada turut mendukung kemajuan pariwisata di suatu daerah, termasuk juga industri perhotelan.

Hotel merupakan salah satu contoh infrastruktur yang mendukung pariwisata di suatu daerah. Terlebih di era digital seperti saat ini, banyak hotel yang melakukan pemasaran digital supaya dapat menjangkau lebih banyak wisatawan. Para wisatawan dapat memilih hotel yang sesuai dengan keinginannya.

Hotel XYZ merupakan salah satu hotel yang menjadi pilihan banyak wisatawan yang berkunjung ke kota Yogyakarta karena letaknya yang ada di jantung kota. Hotel XYZ termasuk kategori hotel bintang 4 yang memiliki banyak fasilitas dan tentu sudah didukung oleh kesiapan teknologi informasi dalam operasional proses bisnisnya. Meskipun hotel ini merupakan bagian dari jejaring hotel di Indonesia yang cukup besar, namun pada prakteknya implementasi teknologi informasi menjadi tanggung jawab dari masing-masing cabang hotel.

Infrastruktur teknologi informasi yang dimiliki oleh hotel XYZ sudah cukup baik. Namun demikian, manajemen hotel belum pernah membuat perencanaan arsitektur teknologi informasi. Semua dilakukan secara spontan dan tanpa standar dokumentasi perancangan yang matang. Hal ini tentu mengakibatkan kendala jika manajemen ingin melakukan perubahan atau perbaikan terhadap suatu sistem. Terbentuknya arsitektur perusahaan merupakan hasil dari perencanaan sebelumnya atau dapat juga terbentuk begitu saja (bersifat $a d-$ hoc). Hal inilah yang terjadi pada Hotel XYZ. Pembuatan sistem yang tidak didasarkan pada arsitektur teknologi informasi dapat menghasilkan sistem pendukung teknologi informasi yang tidak sesuai dengan kebutuhan perusahaan [2].

Implementasi teknologi informasi dalam mendukung proses bisnis Hotel XYZ akan lebih efektif dan efisien apabila didukung oleh sebuah perencanaan arsitektur perusahaan. Alur proses bisnis yang ada memerlukan perbaikan proses bisnis guna meningkatkan kualitas dan mengoptimalkan sistem informasi sumber daya manusia dengan dukungan yang baik dan efisien [3]. Arsitektur perusahaan memiliki sifat mendukung model bisnis fungsional yang dapat disesuaikan dengan berbagai macam kegiatan pelayanan publik [4]. Salah satu manfaat arsitektur enterprise adalah dapat memberikan solusi untuk menyelesaikan masalah arsitektur organisasi, membantu dalam mendokumentasikan desain dan implementasi arsitektur dan fasilitasi kolaborasi dan komunikasi antar pengguna [5].

Arsitektur perusahaan merupakan dasar terbaik organisasi untuk menjelaskan strategi bisnisnya dan masing-masing pengembangan melalui IS/IT [6]. Solusi untuk mengatasi permasalahan tersebut adalah dengan membuat dokumentasi perencanaan suatu arsitektur perusahaan. Arsitektur perusahaan ini akan dibuat untuk mengimplementasikan pemanfaatan teknologi informasi yang tentu sesuai dengan kebutuhan bisnis hotel XYZ.

Arsitektur perusahaan pada penelitian ini akan dilakukan berdasarkan langkah-langkah dalam kerangka kerja The Open Group Architecture Framework (TOGAF). Tahapan yang dilakukan meliputi arsitektur visi, arsitektur bisnis, arsitektur data, arsitektur aplikasi dan arsitektur teknologi.

\section{LANDASAN TEORI}

\section{Enterprise Architecture}

Arsitektur perusahaan adalah suatu instrumen yang digunakan untuk mengartikulasikan arah masa depan perusahaan, sekaligus berfungsi untuk mengarahkan transformasi perusahaan secara aktual [7]. Gagasan utama di balik arsitektur perusahaan adalah kebutuhan perusahaan untuk meninjau, mengembangkan, dan mengendalikan semua bagian perusahaan. Arsitektur perusahaan menurut Steven Spewak terdiri dari arsitektur data, arsitektur aplikasi, arsitektur teknologi [8] [9]. Tahapan utama dalam merancang arsitektur perusahaan dimulai dari identifikasi model bisnis perusahaan dan strategi bisnis perusahaan.

\section{The Open Group Architecture Framework (TOGAF)}

TOGAF adalah kerangka kerja yang membantu organisasi dalam penerimaan, penggunaan, produksi, dan pemeliharaan. TOGAF dikembangkan dan dikelola oleh The Open Group Architecture. Versi pertama TOGAF dikembangkan pada tahun 1995. TOGAF dapat digunakan untuk pengembangan berbagai arsitektur organisasi yang berbeda, TOGAF juga dapat digunakan bersamaan dengan kerangka arsitektur lainnya [10]. TOGAF ADM memiliki alur tahapan seperti Gambar 1.

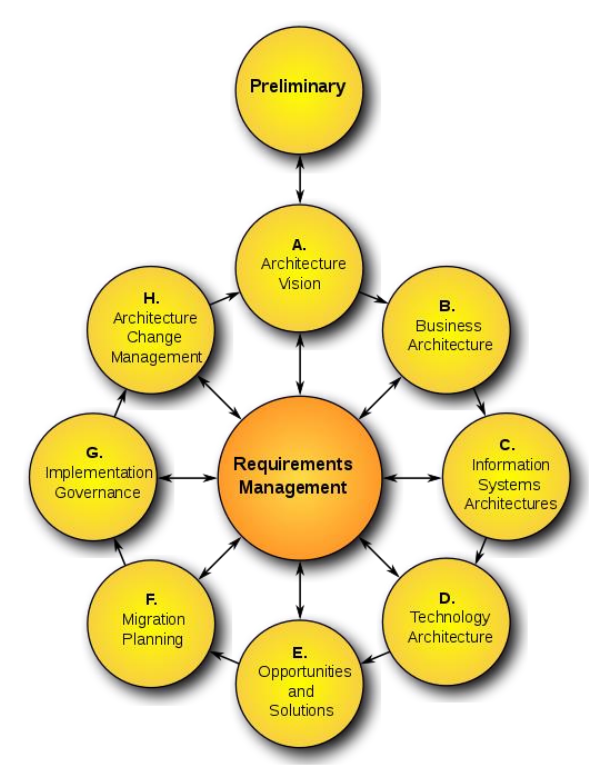

Gambar 1. TOGAF ADM 
Seperti pada Gambar 1, kerangka kerja TOGAF memberikan alur tahapan untuk mengidentifikasi, membangun hingga proses implementasi enterprise architecture [11]. Tahapan yang digunakan pada penelitian perencanaan strategis untuk Hotel XYZ Dengan Metode TOGAF ADM menggunakan beberapa tahapan yang ada pada kerangka TOGAF yaitu :

\section{Preliminary Phase}

Fase pertama ini adalah fase persiapan dalam perancangan kerangka arsitektur. Fase ini berisi cakupan dan prinsip-prinsip yang akan digunakan pada perancangan EA. Pada tahap ini mendefinisikan ruang lingkup organisasi, menentukan framework arsitektur sehingga dapat terarah dengan baik. Tahap ini bertujuan untuk mengkonfirmasi komitmen dari manajemen dan menentukan framework yang digunakan dalam pengembangan EA.

\section{Architecture Vision}

Fase ini digunakan untuk menentukan kebutuhan, dan menggambarkan strategi dan tujuan organisasi. Identifikasi strategi SI/TI dilakukan pada fase ini dengan menginterpretasikan visi, misi, tujuan dan rencana strategis bisnis dari institusi serta tren teknologi saat ini sehingga dapat mendefinisikan SI/TI yang dibutuhkan oleh institusi untuk mendukung proses bisnis.

\section{Business Architecture}

Fase Business Architecture dilakukan pembuatan model arsitektur bisnis sesuai dengan identifikasi proses bisnis yang telah dilakukan sebelumnya dan akan dibuat dalam bentuk analisis rantai nilai (value chain analysis). Analisis rantai nilai digunakan untuk memeriksa dan mengevaluasi seluruh proses bisnis industri, serta sistem spesifik di dalam perusahaan [12].

\section{Information Architecture}

Fase ini dilakukan untuk menggambarkan usulan sistem informasi yang meliputi arsitektur informasi dan arsitektur data untuk memenuhi kebutuhan bisnis organisasi.

\section{Technology Architecture}

Fase ini dilakukan untuk menggambarkan usulan teknologi yang dibutuhkan organisasi. Teknologi yang dirancang berfungsi untuk menjalankan sistem informasi yang telah dirancang sebelumnya.

\section{Opportunities and Solutions}

Fase Opportunities and Solutions adalah fase yang memberikan gambaran secara keseluruhan mengenai kondisi SI/TI Hotel XYZ pada saat ini. Fase ini juga memberikan penjelasan SI/TI mana saja yang membutuhkan perubahan, penambahan, atau tetap menggunakan SI/TI yang sudah ada.

\section{METODE PENELITIAN}

Obyek dari penelitian ini adalah sebuah hotel bintang empat yang terletak di pusat kota Yogyakarta. Metode yang digunakan untuk pengumpulan data adalah wawancara dengan sejumlah pemangku kebutuhan, seperti manajer cabang hotel, dan juga kepala divisi IT dan timnya. Pengambilan data dilakukan selama bulan April 2019 - Juni 2019.

Metode penelitian ini mengacu pada metodologi dan tahapan-tahapan dari perencanaan arsitektur enterprise. Tahapan TOGAF ADM dalam implementasi pada Hotel XYZ dibagi menjadi empat tahapan, yang masing-masing mewakili empat fase dalam TOGAF ADM, yaitu:

1. Identifikasi visi, misi, tujuan, dan kondisi internal dan eksternal Hotel XYZ

2. Identifikasi keadaan arsitektur organisasi

3. Rencana strategis dan portofolio

4. Analisis gap dan solusi

Pada tahapan pertama digunakan untuk menggali informasi terkait Hotel XYZ melalui dokumen perencanaan bisnis dan dokumen yang dianggap penting lainnya serta dilakukan analisis internal dan eksternal perusahaan. Tahapan ini mewakili dua fase dari TOGAF-ADM yaitu preliminary dan architecture vision.

Pada tahapan kedua mengidentifikasi dan mendokumentasikan keadaan arsitektur bisnis, sistem informasi dan teknologi saat ini. Tahapan ini mewakili tiga fase dari TOGAF, yaitu business architecture, information system architecture, dan technology architecture.

Pada tahapan ketiga menyusun rencana strategis dan portofolio SI/TI yang mendukung rencana bisnis dari Hotel XYZ. Tahapan ini juga mewakili tiga fase sebelumnya, yaitu business architecture, information system architecture, dan technology architecture.

Pada tahapan keempat dilakukan analisis kesenjangan yang ada antara keadaan arsitektur saat ini dan rencana strategis. Tahapan ini mewakili fase Opportunities and Solutions.

\section{HASIL DAN PEMBAHASAN}

Sesuai dengan tahapan dalam kerangka kerja pada TOGAF ADM, maka penelitian ini menghasilkan pembahasan yang akan dibagi menjadi empat bagian utama, yaitu:

1. Identifikasi visi, misi, tujuan, dan kondisi internal dan eksternal hotel XYZ

2. Identifikasi keadaan arsitektur organisasi

3. Rencana strategis dan portofolio

4. Analisis gap dan solusi

Masing-masing akan dibahas sebagai berikut:

\section{Identifikasi visi, misi, tujuan, dan kondisi internal dan eksternal hotel XYZ.}

\section{Fase Preliminary: Framework and Principle}

Pada dasarnya hotel XYZ telah menerapkan sistem yang dapat mendukung seluruh operasional hotel, dimana fungsi yang dijalankan hanya dibedakan berdasarkan level karyawan. Meskipun seluruh modul sistem beroperasi secara terpusat, namun di setiap cabang tetap memiliki server masing-masing. Server yang ada di setiap cabang sudah terintegrasi, sehingga manajemen pusat dapat mengakses seluruh data yang ada di 
setiap cabang. Walaupun demikian, jika reservasi dilakukan oleh pelanggan melalui platform afiliasi tiket, maka datanya hanya tersimpan di database masing-masing afiliasi tiket. Menurut manajemen cabang, hal ini dapat menimbulkan masalah, yaitu ketika pelanggan telah melakukan reservasi di salah satu platform afiliasi tiket namun informasi tersebut tidak berhasil diteruskan ke Hotel XYZ karena media penyimpanan email yang penuh, sehingga mengakibatkan proses check-in menjadi lebih panjang. Dengan menerapkan solusi integrasi data dengan database afiliasi tiket, diharapkan dapat mereduksi miskomunikasi serta meningkatkan kecepatan dalam proses check-in.

Pada tahapan preliminary ini dihasilkan artefak berupa principle catalog pada Hotel XYZ seperti terlihat pada Tabel 1. Hal ini berfungsi untuk mencatat prinsip-prinsip perancangan yang akan dibuat. Katalog ini selanjutnya akan digunakan untuk menyatakan visi dan prinsip yang jelas tentang bagaimana melakukan pengembangan arsitektur perusahaan.

Tabel 1. Principle Catalog Hotel XYZ

\begin{tabular}{|c|c|c|}
\hline No & Prinsip & Deskripsi \\
\hline 1 & Business Principal & $\begin{array}{l}\text { - Arsitektur enterprise } \\
\text { yang dibuat harus sesuai } \\
\text { dengan kebutuhan fungsi } \\
\text { bisnis hotel } \\
\text { - Prinsip yang dibuat harus } \\
\text { berlaku pada setiap } \\
\text { bagian hotel } \\
\text { - Pengelolaan arsitektur } \\
\text { enterprise harus lebih } \\
\text { mudah dan efisien } \\
\text { sehingga meningkatkan } \\
\text { proses bisnis hotel }\end{array}$ \\
\hline 2 & Data Principal & $\begin{array}{l}\text { - Data dikelola dengan } \\
\text { baik dan memastikan } \\
\text { data yang disimpan } \\
\text { akurat dan bisa diakses } \\
\text { kapanpun, dimanapun. } \\
\text { - Data yang disimpan } \\
\text { konsisten dan dapat } \\
\text { dimengerti oleh semua } \\
\text { user di hotel } \\
\text { Data dilindungi dan tidak } \\
\text { dapat diakses di luar } \\
\text { otoritas hotel. }\end{array}$ \\
\hline 3 & Application Principal & $\begin{array}{l}\text { - Aplikasi dapat berjalan } \\
\text { di berbagai platform } \\
\text { sehingga aplikasi dapat } \\
\text { mudah dikembangkan } \\
\text { dan di operasikan dengan } \\
\text { baik } \\
\text { - Aplikasi harus mudah } \\
\text { digunakan oleh } \text { user } \\
\text { sehingga proses bisnis di } \\
\text { Hotel XYZ bisa berjalan } \\
\text { dengan baik }\end{array}$ \\
\hline
\end{tabular}

\begin{tabular}{|c|c|c|}
\hline 4 & Technology Principal & $\begin{array}{l}\text { - Arsitektur harus } \\
\text { dirancang untuk } \\
\text { memudahkan perubahan } \\
\text { dan pengembangan } \\
\text { kedepannya nanti. } \\
\text { - Menggunakan hardware, } \\
\text { software dan platform } \\
\text { yang distandarkan } \\
\text { supaya data yang } \\
\text { digunakan kompitabel } \\
\text { dan akurat. }\end{array}$ \\
\hline
\end{tabular}

Fase Architecture Vision

Identifikasi dilakukan menggunakan tools Business Model Canvas seperti terlihat pada Gambar 2 untuk menggambarkan dasar pemikiran tentang bagaimana sebuah organisasi menciptakan, menyampaikan dan menangkap nilai [13].

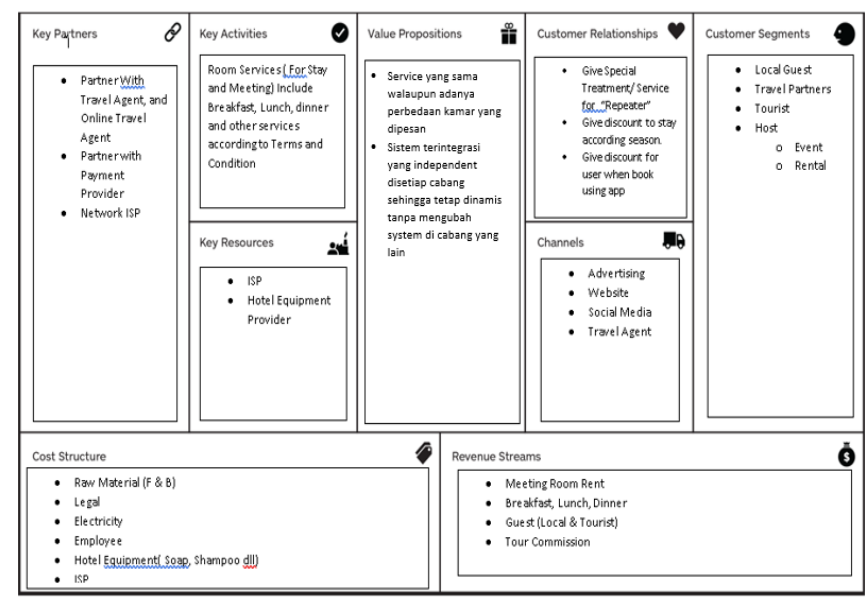

Gambar 2. Business Model Canvas Hotel XYZ

Pada fase Architecture Vision ini dihasilkan artefak berupa business model canvas yang menggambarkan elemen-elemen utama yang menggerakkan bisnis hotel XYZ. Sembilan elemen utama ini secara detail akan dijelaskan sebagai berikut:

\section{Customer Segment}

Customer Segment Hotel XYZ menyasar kepada Local Guest atau tamu lokal, turis luar negeri, travel partners (Tour), Host (Event dan Meeting) untuk menyewakan ruang untuk menginap, mengadakan meeting, dan event seperti seminar, ulang tahun, dan lain-lain.

\section{Value Propotition}

Berada di pusat kota dan dekat dengan tempat tujuan wisata, serta mempunyai citra yang baik di mata publik menjadi nilai tersendiri bagi Hotel XYZ. Selain itu ada analisis lain jika dipandang dari sisi eksternal dan internal adalah sebagai berikut: Jika dipandang dari eksternal, hotel ini hanya menawarkan dua jenis kamar yaitu deluxe dan superior, namun kedua kamar tersebut tetap mendapatkan service yang sama dimana perbedaaannya hanyalah fasilitas yang didapatkan di kamar deluxe lebih mewah dan lebih lengkap. Jika dipandang dari internal, hotel ini menggunakan satu 
sistem untuk aktivitas operasional pada seluruh divisi dan juga digunakan untuk setiap cabang. Namun, setiap cabang dapat melakukan penambahan menu untuk disesuaikan pada setiap kebutuhan di daerah cabang tersebut tanpa mengganggu sistem di cabang lainnya. Perubahan sistem kepada seluruh cabang hanya dapat dilakukan oleh kantor pusat.

\section{Customer Relationship}

Hotel XYZ menjaga hubungan pelanggan dengan memberikan pelayanan ekstra untuk customer yang sudah beberapa kali menginap di Hotel XYZ, dengan cara memberikan potongan harga, hadiah ulang tahun, dan berbagai macam layanan lainnya. Selain itu Hotel XYZ juga menyediakan aplikasi untuk memesan hotel yang dimana data customer disimpan dan poin dapat ditukarkan untuk layanan yang diberikan.

\section{Key Activities}

Aktivitas utama dalam Hotel XYZ adalah menyediakan layanan untuk menginap dengan memberikan service yang baik mulai dari pelayanan ruangan, makanan, dan layanan lainlain sesuai dengan ketentuan yang ada berlaku di Hotel XYZ.

\section{Key Resource}

Sumber daya yang diperlukan hotel XYZ adalah penyedia jasa internet service provider \& hotel equipment provider yang digunakan untuk operasional dan layanan kamar dalam hotel.

\section{Cost Structure}

Cost Structure yang dikeluarkan untuk operasional hotel XYZ adalah berupa raw material untuk divisi F\&B (makanan dan minuman), kebutuhan legal atau perizinan untuk menjalankan bisnis hotel, izin ganguan, izin mendirikan bangunan, electricity/listrik untuk operasional seperti AC, lampu, wifi, telepon, televisi, dan infrastruktur lainnya, kebutuhan hotel equipment yang mendukung layanan hotel terhadap tamu, seperti pengadaan peralatan mandi untuk tamu, serta layanan penyedia internet untuk kebutuhan WIFI customer dan untuk akses internet dalam office/kantor internal Hotel XYZ. Selain itu juga kebutuhan untuk sumber daya manusia sebagai orang yang berperan dalam bisnis, pelayanan, teknisi, dan karyawan lainnya.

\section{Revenue Stream}

Revenue stream yang didapatkan Hotel XYZ melalui pemasukan dari tamu yang menginap lokal/turis. Selain itu juga persewaan meeting room dan dari agen travel.

Selain Business Model Canvas, pada fase ini menggunakan analisis rantai nilai, seperti pada Gambar 3.

\section{Porter's Value Chain Analysis}

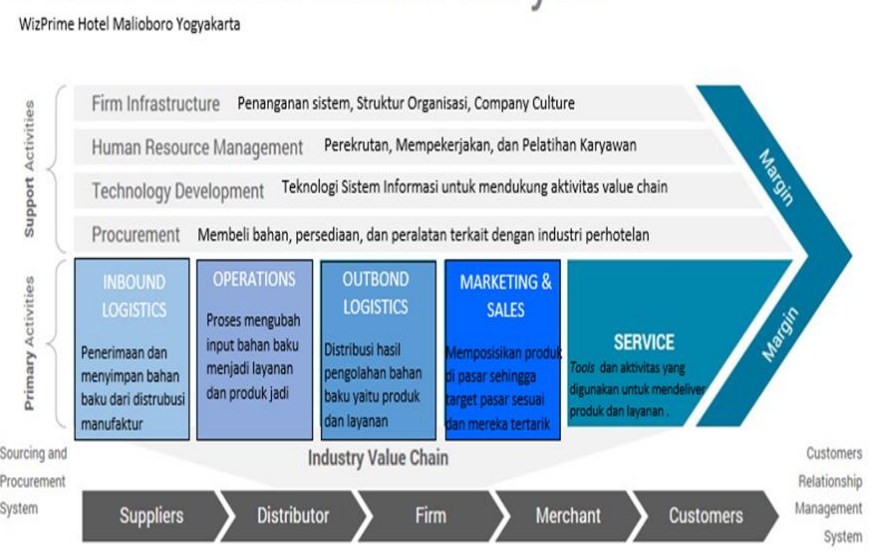

Gambar 3. Porter's Value Chain Analysis Hotel XYZ [14]

\section{Support Activities}

a. Firm Architecture

Infrastruktur industri perhotelan diwakili oleh tim manajemen yang telah melakukan perencanaan jangka panjang, manajemen kualitas produk atau layanan, urusan publik, keuangan, dan akuntansi. Secara umum, seluruh infrastruktur di perusahaan mendukung seluruh rantai kegiatan yang menghasilkan nilai. Penanganan sistem berfungsi sebagai prosedur untuk mengoperasikan seluruh infrastruktur berdasarkan standard operational procedure yang telah ditentukan oleh manajemen Hotel XYZ. Struktur organisasi menjadi bagian garis koordinasi terkait dengan pengoperasian infrastruktur. Company Culture atau budaya perusahaan dibutuhkan karena terkait dengan seluruh divisi yang ada di struktur organisasi sehingga terjalin sinergi yang baik dalam koordinasi terkait penggunaan infrastruktur maupun non infrastruktur.

\section{b. Human Resource Management}

Sumber daya di seluruh divisi pada industri perhotelan memerlukan sinergi yang tinggi untuk menghasilkan pelayanan yang maksimal terutama sumber daya manusia. Manajemen diperlukan untuk mengelola seluruh sumber daya manusia sehingga menghasilkan budaya yang baik untuk mencerminkan kualitas dari hotel tersebut. HR Management mengelola seluruh SDM tanpa terkecuali mulai dari awal perekrutan hingga membentuk kualitas kinerja yang baik pada seluruh karyawan hotel XYZ.

\section{c. Technology Development}

Penerapan teknologi sangatlah penting untuk mengikuti perkembangan digital namun harus disesuaikan dengan kebutuhan bisnis. Hotel XYZ menggunakan sistem operasional yang dijual oleh pengembang luar namun di modifikasi oleh tim development internal Hotel XYZ sehingga sesuai dengan kebutuhan. Seluruh sistem yang dipakai sebenarnya adalah satu sistem dimana menu dan fungsinya berbeda-beda sesuai hak akses setiap divisi. Modifikasi sistem dapat terjadi hanya di satu cabang tanpa mengganggu sistem di cabang lainnya. Hal ini karena penggunaan akan disesuaikan 
dengan setiap daerah cabang, namun modifikasi system dilakukan bukan terhadap fungsi utama pada sistem. Modifikasi internal cabang dapat dilakukan hanya ketika telah disetujui oleh kantor pusat. Sedangkan modifikasi fungsi utama pada sistem hanyalah dapat dilakukan oleh pihak kantor pusat dimana akan ada pemberitahuan untuk setiap cabang untuk melakukan implementasi bergilir.

\section{d. Procurement}

Proses pengadaan di industri perhotelan terkait dengan fasilitas yang ditawarkan kepada tamu, kebutuhan bangunan, dan peralatan pendukung untuk mendukung seluruh aktivitas operasional. Hal ini bertujuan untuk membuat layanan atau produk baru dan menberikan layanan menjadi lebih mudah dan lancar.

\section{Primary Activities}

a. Inbound Logistics

Menjalin hubungan kerjasama dengan supplier bahan baku, peralatan operasional, dan peralatan perhotelan seperti peralatan mandi dan lain sebagainya, dimana ada penanganan kontrol terhadap inventaris dan permintaan stok. Kemudian adanya kerjasama dengan laundry disekitar untuk layanan tambahan bagi customer. Pembelian stok telah disesuaikan dengan standar yang telah ditentukan sehingga dapat memenuhi kebutuhan tamu ketika terjadi permintaan yang tidak terduga.

\section{b. Operations}

Kegiatan ini terkait dengan operasional yang ada di Hotel XYZ. Semua kegiatan dijalankan sesuai prosedur yang telah ditetapkan dimana beberapa operasi dilakukan dengan bantuan teknologi sehingga menghasilkan barang dan jasa untuk ditawarkan ke pasar.

\section{c. Outbound Logistics}

Kegiatan ini terkait dengan cara mendistribusikan layanan dan produk yang telah dihasilkan dari kepada calon customer. Distribusi dilakukan sesuai dengan prosedur yang telah dijadwalkan dan jaringan distribusi yang telah ditentukan.

\section{d. Marketing \& Sales}

Seluruh kegiatan yang bertujuan untuk mendapatkan customer yang tertarik terhadap layanan dan produk yang ditawarkan dengan menonjolkan iklan dan harga yang value for money untuk bersaing dengan kompetitor. Aktivitas ini terkait dengan kegiatan pemasaran, periklanan, menentukan harga produk, pemilihan saluran atau media untuk periklanan sehingga sesuai dengan target pasar yang telah ditentukan.

\section{e. Service}

Layanan dalam industri perhotelan merupakan elemen yang sangat penting dan krusial terhadap keberhasilannya bisnisnya. Kualitas service yang ditawarkan tentunya melibatkan sejumlah karyawan tertentu sesuai dengan kemampuan yang telah ditentukan dan dilatih secara berkala. Jika layanan yang ditawarkan cenderung baik, maka akan menjadi pertimbangan bagi tamu yang telah pernah menginap ataupun calon tamu baru untuk menginap kembali. Penyampaian layanan saat ini tentunya dibantu dengan tools untuk mendukung aktivitas tersebut sehingga dapat menghasilkan output yang lebih maksimal terkait value delivery.

\section{Identifikasi Keadaan Arsitektur Organisasi}

\section{Fase Business Architecture}

Pada fase ini, alat analisis yang digunakan adalah Analisis SWOT. Analisis kekuatan, kelemahan, peluang dan ancaman atau dikenal sebagai Analisis SWOT adalah perangkat yang membantu manajer bisnis untuk mengevaluasi kekuatan, kelemahan, peluang, dan ancaman yang terlibat dalam perusahaan bisnis. Analisis SWOT dapat membantu mereka mendapatkan wawasan dari semua yang perusahaan sudah lakukan dan memikirkan kemungkinan solusi untuk masa depan.

Strength:

1. Lokasi strategis dekat stasiun kereta api dan pusat kota Yogyakarta

2. Infrastruktur IT untuk keperluan pengelolaan data pelanggan dan perusahaan sudah tersedia (tersedia aset server, database, koneksi internet, personal computer yang memadai)

3. Penyedia jasa internet yang berbeda (ISP untuk Internal dan Telkom untuk Pelanggan/Public) menjamin atau memperkecil peluang kebocoran rahasia perusahaan dan customer kepada publik

4. Sudah bekerjasama dengan afiliasi tiket

Weakness:

1. Database reservasi pelanggan di afiliasi tiket (Traveloka) belum terintergasi sepenuhnya, meskipun pihak Hotel XYZ memiliki akun resmi untuk dapat masuk ke database reservasi pelanggan, namun pelaporan reservasi masih melalui e-mail. Hal ini mengakibatkan kemungkinan data reservasi tidak diterima dengan baik atau hilang.

2. Tipe kamar hanya tersedia 2 jenis yaitu superior dan deluxe, tidak ada tipe kamar lain untuk segmen pasar lain. Mengingat letak hotel yang dekat dengan kawasan wisata dan stasiun ada kemungkinan bahwa yang menginap merupakan turis yang berlibur.

\section{Opportunity:}

1. Peluang untuk mendapatkan banyak pelanggan semakin meningkat dengan pertumbuhan pariwisata di Yogyakarta dan dekatnya dengan stasiun. Selain itu dukungan pemerintah dan investor untuk meningkatkan pariwisata di Indonesia juga besar.

2. Semakin mudah dan praktisnya metode pembayaran membuat pembayaran atau reservasi hotel menjadi lebih mudah bagi pelanggan.

3. Semakin mudahnya tranportasi umum di Yogyakarta yang membuat akses ke Hotel XYZ menjadi lebih mudah. 
Threat:

1. Peraturan pemerintah mengenai dilarangnya pengadaan rapat di hotel mengancam pemasukan Hotel XYZ yang segmentasi pasar utamanya adalah eksekutif muda.

2. Adanya pesaing lain yang juga ada di wilayah atau area yang sama.

Strategi SO:

1. Memperbanyak promosi produk atau jasa yang ditawarkan di Hotel XYZ.

2. Memperkuat CRM yang ada di Hotel XYZ untuk mempertahankan pelanggan yang ada dan mencari pelanggan baru sebanyak-banyaknya.

Strategi ST:

1. Memperluas pangsa pasar dengan memanfaatkan kekuatan yang ada yaitu tempat yang dekat dengan stasiun kereta api. Tidak hanya berfokus pada para eksekutif tetapi juga keluarga atau turis-turis yang sedang berlibur.

2. Membuat promo yang menarik dan meningkatkan pelayanan kepada pelanggan dengan membedakan setiap promo sesuai dengan tingkat loyalitas pelanggan agar setiap pelanggan merasa diistimewakan.

Strategi WO:

1. Mengintegrasikan basis data yang ada di sistem internal Hotel XYZ dengan sistem basis data perusahaan afiliasi tiket (Traveloka).

2. Menambahkan tipe kamar baru yang berorientasi tidak hanya segmentasi pasar untuk eksekutif tetapi juga untuk turis yang sedang berlibur di Jogja.

Strategi WT:

1. Merubah strategi dan orientasi pasar serta tetap berusaha bekerja sama dengan perusahaan lain agar informasi yang didapat semakin lengkap.

2. Mencari keunikan dari perusahaan dan meningkatkan pelayanan dan kinerja perusahaan dengan sistem yang leih baik dan akurat dalam pengolahan data.

Analisis SWOT ini menghasilkan beberapa strategi yang lebih banyak berkaitan dengan manajemen hubungan pelanggan. Selain SWOT, fase ini juga mendefinisikan proses bisnis yang terjadi di Hotel XYZ, dan digambarkan dalam Diagram Proses Bisnis. Diagram proses bisnis adalah representasi visual dari salah satu proses bisnis inti organisasi. Diagram proses bisnis akan menampilkan rangkaian aktivitas atau tugas secara visual.

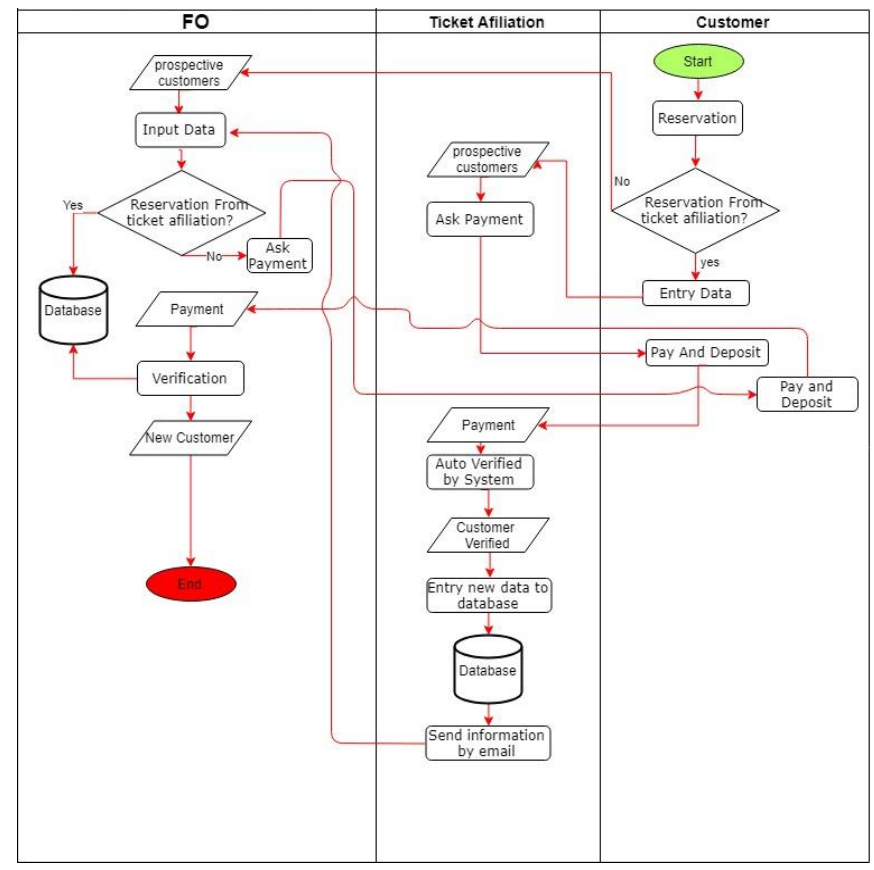

Gambar 4. Flow Chart Reservasi (Current State)

Gambar 4 merupakan alur aktivitas saat ini yang terjadi ketika tamu melakukan reservasi hotel baik melalui sistem tiket afiliasi ataupun langsung datang ke hotel.

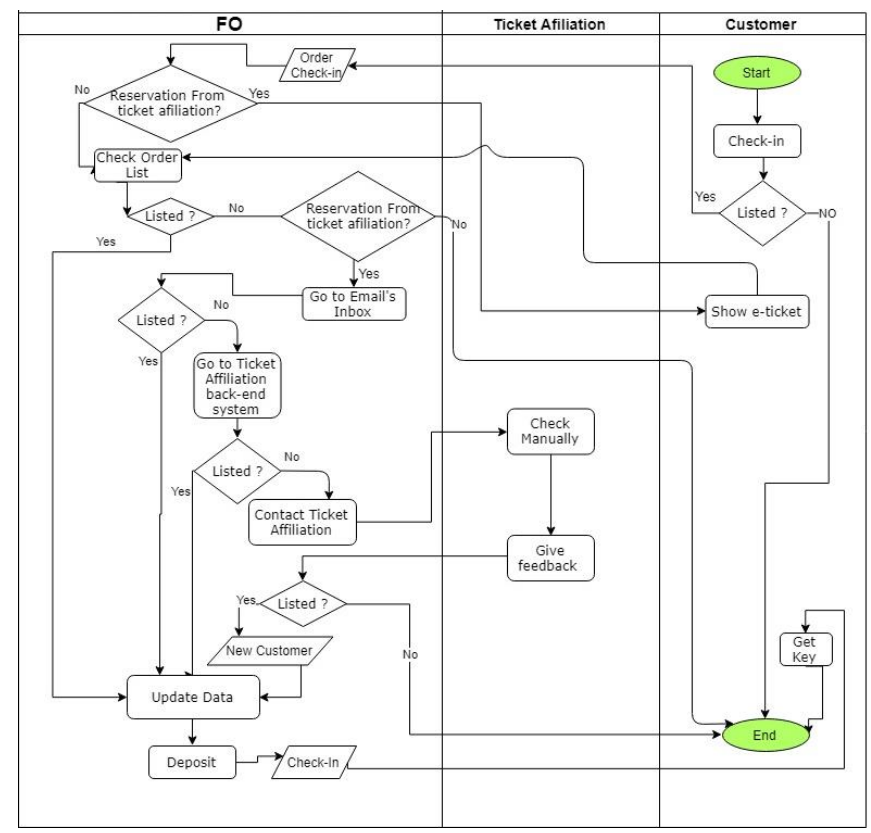

Gambar 5. Flow Chart Check-In (Current State)

Gambar 5 merupakan alur aktivitas saat ini yang terjadi ketika tamu melakukan proses check in hotel, baik yang melakukan reservasi melalui sistem tiket afiliasi ataupun langsung datang ke hotel. 


\section{Fase Information System Architecture}

Pada tahap ini dilakukan identifikasi kondisi saat ini dari sistem informasi dan teknologi informasi yang telah diimplementasikan di Hotel XYZ, seperti terlihat dalam Tabel 2 yang menjelaskan fungsi dari aset aplikasi yang dimiliki hotel, beserta dengan pengguna aplikasinya.

Tabel 2. Arsitektur Sistem Informasi Hotel XYZ

\begin{tabular}{lll}
\hline Nama Aplikasi & \multicolumn{1}{c}{ Fungsi } & Pengguna \\
\hline $\begin{array}{l}\text { Website Profile } \\
\text { Company dan } \\
\text { Reservasi }\end{array}$ & $\begin{array}{l}\text { Memesan/booking kamar dan } \\
\text { menampilkan profil } \\
\text { organisasi }\end{array}$ & Customer \\
\hline Aplikasi & Memesan/booking kamar dan & Customer \\
Android Hotel & menyimpan poin customer & \\
XYZ & yang nantinya dapat di & \\
& redeem & \\
\hline Sistem All in & - Mengelola data customer & Front \\
One Control & yang memesan booking & Office, \\
(Reservation, & kamar langsung di tempat & Accounting, \\
Karyawan. & - Mengelola data karyawan, & HRD, \\
Inventory, & presensi, serta penggajian & House \\
Room, Facility) & - Mengelola data bahan & Keeping \\
& baku, equipment dan supply & Manajer \\
& peralatan hotel & \\
& - Mengelola seluruh kamar & \\
& dan fasilitas yang ada & \\
\hline
\end{tabular}

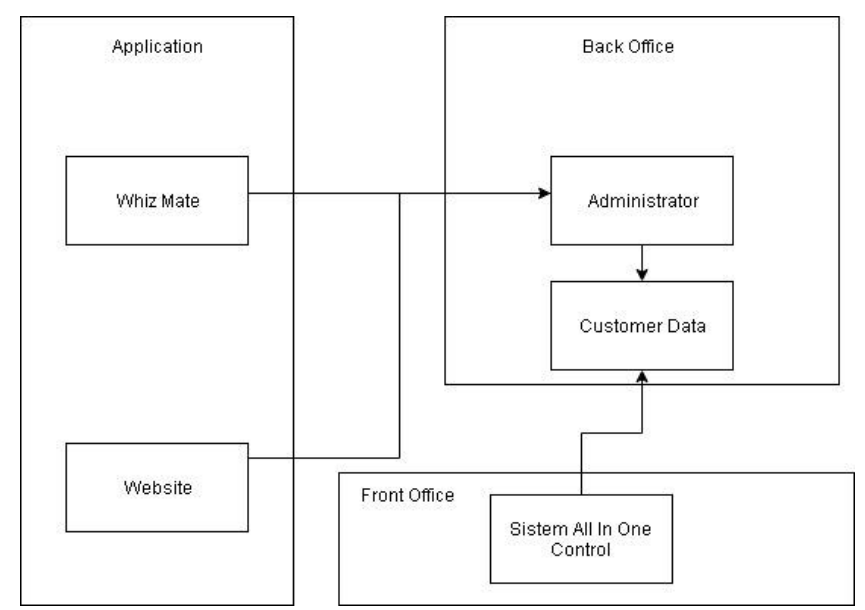

Gambar 6. Arsitektur Aplikasi

Dengan berbagai aplikasi yang disediakan saat ini, dapat dikatakan sudah cukup mendukung proses bisnis Hotel XYZ. Aplikasi tersebut berfungsi untuk melakukan reservasi hotel dan menyimpan data pelanggan seperti nama, umur, tanggal lahir, dan alamat.

Selain itu sistem informasi berbasis web yang digunakan oleh Hotel XYZ untuk saat ini hanya berfungsi untuk mengecek ketersediaan kamar dan melakukan reservasi. Sistem ini terpusat sehingga terdapat pilihan untuk reservasi di Hotel XYZ cabang mana saja dengan arsitektur aplikasi seperti terlihat pada Gambar 6. Aplikasi Reservasi Front Office adalah aplikasi biasa yang digunakan perhotelan untuk membuat reservasi secara langsung ditempat dan biasanya akan menyimpan data dari KTP dan nomor telepon, data tersebut akan disimpan oleh resepsionis yang nantinya akan digunakan untuk membuat laporan.

\section{Rencana Strategis dan Portofolio}

Pada tahap ini dilakukan pendefinisian kebutuhan sistem informasi dan teknologi informasi yang mengacu pada analisis internal dan eksternal lingkungan bisnis serta dokumen tugas pokok dan fungsi organisasi.

\section{Fase Opportunities and Solution}

a. Usulan Sistem Informasi

Hasil dari analisis internal dan eksternal bisnis kemudian digunakan untuk menentukan pola solusi sistem informasi yang akan mendukung proses bisnis di lingkungan organisasi. Hasil analisis kebutuhan sistem informasi dapat diuraikan dalam Tabel 3. Sedangkan Gambar 7 dan Gambar 8 memperlihatkan alur proses bisnis reservasi dan check-in hotel mendatang.

Tabel 3. Usulan aplikasi solusi SI Hotel XYZ

\begin{tabular}{lll}
\hline \multicolumn{1}{c}{ Unit } & \multicolumn{1}{c}{ Tujuan } & \multicolumn{1}{c}{ Solusi SI } \\
\hline Front & Mengintegrasikan database & Platform portal \\
Office & sehingga data terpusat pada & penyimpanan \\
& satu platform. Sehingga & seluruh data \\
& mengurangi aktivitas & customer yang \\
& penanganan saat terjadi & terintegrasi dengan \\
& masalah reservasi melalui & database afiliasi \\
& afiliasi tiket & tiket \\
\hline
\end{tabular}

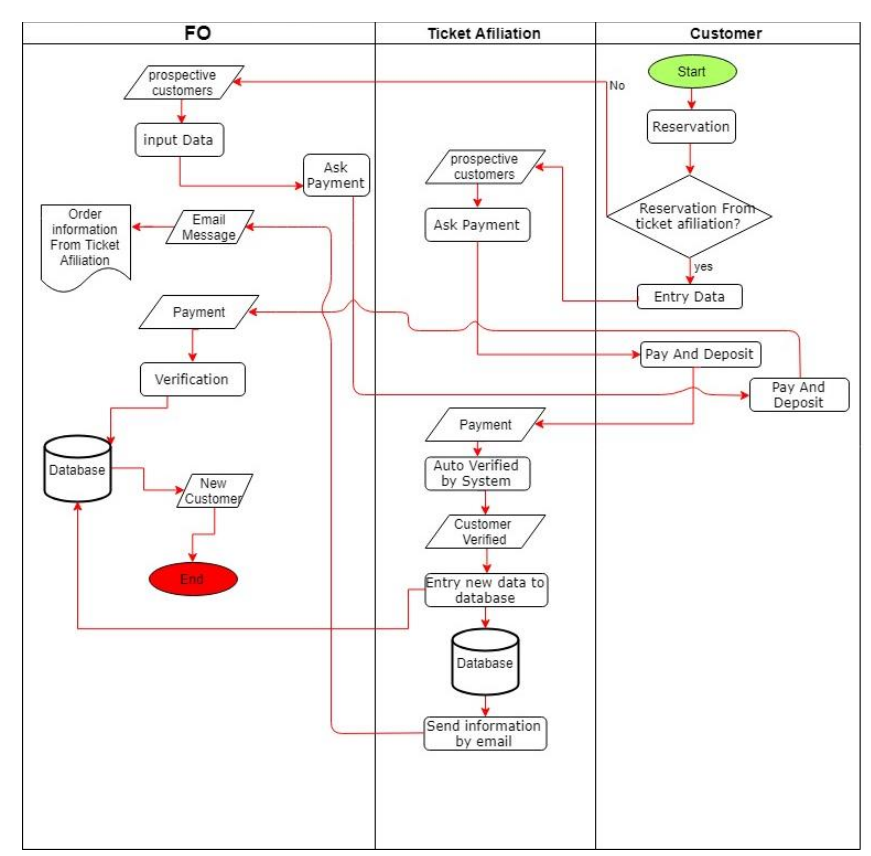

Gambar 7. Flow Chart Reservasi (Future State) 


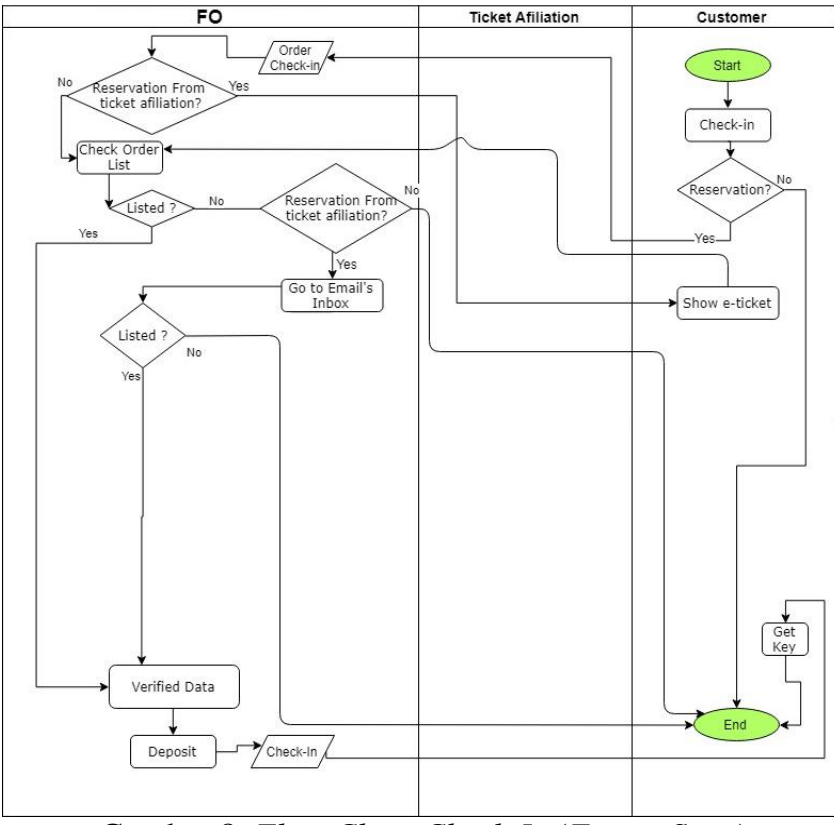

Gambar 8. Flow Chart Check-In (Future State)

b. Usulan Arsitektur Teknologi

Tujuan pada tahap ini adalah menentukan platform teknologi yang menjadi lingkungan bagi sistem informasi untuk mendukung proses bisnis. Teknologi yang dibutuhkan yaitu teknologi jaringan komputer untuk menghubungkan sistem informasi yang ada serta diperlukan penambahan beberapa perangkat keras. Perbandingan arsitektur teknologi antara kondisi saat ini dan yang diusulkan dapat dilihat pada Gambar 9.

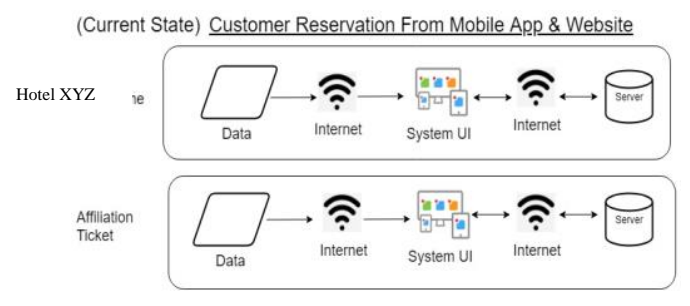

(Future State) Customer Reservation From Mobile App \& Website

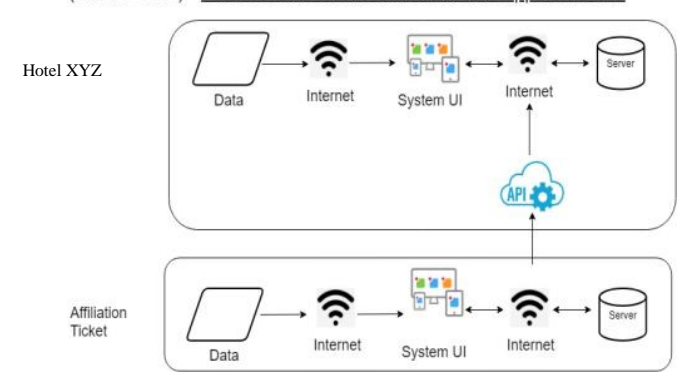

Gambar 9. Usulan Arsitektur Teknologi

\section{Analisis Gap dan Solusi}

Untuk mendapatkan gambaran umum tentang kesenjangan SI/TI di lingkungan organisasi, maka diperlukan analisis dengan melihat dari dua komponen utama yaitu sistem informasi dan infrastruktur. Dari hasil kondisi sistem informasi saat ini dapat dilakukan perbandingan dengan usulan SI, dapat dirangkum dalam Tabel 4. Sedangkan Tabel 5 menjelaskan usulan bagi hotel untuk mempertahankan aset infrastruktur mana yang dapat dipertahankan dan perlu diperbaiki.

Tabel 4. Analisis Gap dan Solusi Perencanaan Strategis Sistem Informasi Hotel XYZ

\begin{tabular}{clll}
\hline Unit & Tujuan Bisnis & \multicolumn{1}{c}{ SI Saat Ini } & \multicolumn{1}{c}{ Usulan SI } \\
\hline Front & Mencegah & Sistem All in One & Update \\
Office & terjadinya & Control yang & Sistem All in \\
& miskomunikasi & tidak & One Control \\
& data reservasi & mengintegrasikan & sehingga data \\
& dan mengurangi & data dengan & dengan \\
& proses & afiliasi tiket & afiliasi tiket \\
& penanganannya & & terintegrasi \\
& serta & menggunakan \\
& mengintegrasikan & & API \\
& dengan seluruh & & \\
& data reservasi & & \\
& afiliasi tiket yang & & \\
& terkait & & \\
\hline
\end{tabular}

Tabel 5. Kondisi Infrastruktur TI Hotel XYZ

\begin{tabular}{|c|c|c|c|}
\hline $\begin{array}{c}\text { Infra } \\
\text { struktur }\end{array}$ & Ideal & $\begin{array}{l}\text { Kondisi } \\
\text { Saat Ini }\end{array}$ & Aksi \\
\hline$P C$ & $\begin{array}{l}\text { Jumlah yang telah } \\
\text { memadai dan } \\
\text { spesifikasi telah sesuai } \\
\text { kebutuhan }\end{array}$ & sesuai & retain \\
\hline Antivirus & $\begin{array}{l}\text { Telah menerapkan } \\
\text { antivirus yang dapat } \\
\text { memproteksi data } \\
\text { dengan baik dan tidak } \\
\text { pernah ada data yang } \\
\text { terindikasi terkena hack }\end{array}$ & sesuai & retain \\
\hline Switch & $\begin{array}{l}\text { Jumlah Switch telah } \\
\text { disesuaikan dengan } \\
\text { device yang ada } \text { untuk } \\
\text { setiap lantai adalah satu } \\
\text { switch per ruangan } \\
\text { namun dibedakan } \\
\text { dengan dengan switch } \\
\text { tambahan jika ada ruang } \\
\text { meeting }\end{array}$ & sesuai & retain \\
\hline ISP & $\begin{array}{l}\text { Tidak memiliki kendala } \\
\text { terkait jaringan untuk } \\
\text { operasional organisasi }\end{array}$ & sesuai & retain \\
\hline $\begin{array}{l}\text { Entreprise } \\
\text { Firewall }\end{array}$ & $\begin{array}{l}\text { Belum memproteksi } \\
\text { data dari platform } \\
\text { aplikasi afiliasi tiket }\end{array}$ & $\begin{array}{l}\text { dapat } \\
\text { mempro } \\
\text { teksi } \\
\end{array}$ & update \\
\hline $\begin{array}{l}\text { Data } \\
\text { center }\end{array}$ & $\begin{array}{l}\text { Server yang digunakan } \\
\text { adalah server pribadi } \\
\text { untuk setiap cabang dan } \\
\text { aplikasi yang diterapkan } \\
\text { dapat berjalan optimal }\end{array}$ & sesuai & retain \\
\hline $\begin{array}{l}\text { Database } \\
\text { Manage } \\
\text { ment } \\
\text { System }\end{array}$ & $\begin{array}{l}\text { Relasi antar entitas akan } \\
\text { mengalami perubahan } \\
\text { serta atribut dari } \\
\text { beberapa entitas juga } \\
\text { akan diubah sehingga } \\
\text { dapat menerapkan } \\
\text { database terintegrasi }\end{array}$ & $\begin{array}{l}\text { belum } \\
\text { support }\end{array}$ & update \\
\hline
\end{tabular}




\section{KESIMPULAN}

Sistem informasi menjadi landasan bagi pengembangan sebuah organisasi modern [15]. Oleh karenanya setiap organisasi perlu didukung oleh rancangan arsitektur sistem informasi untuk pengembangan bisnis organisasinya [16]. Sebagai bagian dari salah satu hotel chain yang cukup dikenal di Indonesia, Hotel XYZ mempunyai harapan bahwa perencanaan strategi SI/TI akan mendukung efektifitas dan efisiensi proses bisnis organisasi. Berdasarkan hasil analisis SWOT dihasilkan strategi bisnis Hotel XYZ yang lebih banyak berkaitan dengan unit marketing. Optimalisasi strategi bisnis tentunya dapat didukung dengan strategi TI, contohnya pemanfaatan digital marketing. Penelitian ini juga mengusulkan satu sistem untuk perbaikan unit front office, dimana sistem all in one control yang saat ini dimiliki oleh Hotel XYZ dengan basis data terpusat dapat terintegrasi dengan platform afiliasi sistem tiket lainnya menggunakan API. Usulan strategi SI untuk unit front office ini juga didukung dengan usulan arsitektur teknologinya. Selain itu juga menghasilkan daftar asset infrastruktur TI mana saja yang perlu dipertahankan dan ditingkatkan.

\section{REFERENSI}

[1] Tugu Jogja. (2019). Sektor Pariwisata Duduki Peringkat ke-2 Penyumbang PDRB di Yogyakarta. Diakses dari: https://kumparan.com/tugujogja/dari-17-sektor-usahapenyumbang-pdrb-di-yogyakarta-pariwisatamenduduki-peringkat-kedua/full.

[2] Prasetyo, T.F. (2015). Perancangan Arsitektur Sistem Informasi Rumah Sakit Kabupaten (Studi Kasus RSUD Majalengka ). Infotech Journal, Vol. 1(1), pp. 34-48.

[3] Sofyana, L. \& Putera, A.R. (2019). Business Architecture Planning with TOGAF Framework. Journal of Physics: Conference Series, Vol. 1375. DOI: 10.1088/1742-6596/1375/1/012056.

[4] Widjajarto, A., Lubis, M. \& Yunan, U. (2019). Architecture Model of Information Technology Infrastructure Based on Service Quality at Government Institution. Procedia Computer Science, Vol. 161, pp. 841-850. DOI: 10.1016/j.procs.2019.11.191.
[5] Taleb, M. \& Cherkaoui, O. (2012). Pattern-Oriented Approach for Enterprise Architecture: TOGAF Framework. Journal of Software Engineering and Applications, Vol. 5(1), pp. 45-50.

[6] Azevedo, P.S., Azevedo, C. \& Romao, M. (2013). Enterprise Architecture Model: an Approach Proposition - a Case Study of Information Systems in the Hospitality Industry. Proceeding of the International Conference on Advances in Computing, Electronics and Communication, pp. 1-6.

[7] Danny, G. \& Erik, P. (2011). Architecture Principles. Springer.

[8] Spewak, S.H. \& Hill, S.C. (1993). Enterprise Architecture Planning: Developing a Blueprint for Data, Applications, and Technology. QED Publishing Group.

[9] Greefhorst, D. \& Proper, E. (2011). Architecture Principles. Springer.

[10] Haren, V. (2011). TOGAF Version 9.1: A Pocket Guide. Van Haren Publishing.

[11] The Open Group. (2011). Module 2 - Togaf 9 Components. TOGAF Standard Courseware V9 Ed., pp. 311-312.

[12] Zamora, E.A. (2016). Value Chain Analysis: A Brief Review. Asian Journal of Innovation Policy, vol. 5(2), pp. 116-128, 2016. DOI: 10.7545/ajip.2016.5.2.116.

[13] Umar, A., Sasongko, A.H., Aguzman, G. \& Sugiharto. (2018). Business Model Canvas as a Solution for Competing Strategy of Small Business in Indonesia. International Journal of Entrepreneurship, vol. 22(1), pp. 1-9.

[14] Ensign, P.C. (2001). Value Chain Analysis and Competitive Advantage. Journal of General Management, Vol. 27(1), pp. 18-42.

[15] Goepp, V. \& Petit, M. (2017). Insight From a Comparison of TOGAF ADM and SAM Alignment Processes. IFAC-PapersOnLine, vol. 50(1), pp. 1170711712. DOI: 10.1016/j.ifacol.2017.08.1693.

[16] Thaib, F. \& Emanuel, A.R. (2020). Perancangan Enterprise Architecture UNIPAS Morotai Menggunakan TOGAF ADM. Teknika, vol. 9(1), pp. 1-8. DOI: 10.34148/teknika.v9i1.247. 